\title{
Modelando diálogos e compondo traduções a partir da poética de Sara Ramos
}

Ana Paula Sabiá*

RESUMO: De onde iniciar a ver/ler a obra de Sara Ramos? Desejo partir dos dispositivos do discurso e do saber, além de percepções subjetivas, com o intuito de operar em algumas possibilidades de tradução. Além disso, me agrada a ideia de buscar uma possibilidade de compreensão de sua obra a partir de diálogos com a minha própria fatura artística. Tal desafio é assumir caminhar junto dela - e me por à prova - em um limiar de transmutação poética ou, como diria Benjamim, traição. Apesar de o conceito de tradução inscrever-se em uma herança racional que pretende estabelecer uma espécie qualquer de ordem ao caos, um tradutor é antes ser criador, ser imaginativo que interpreta a seu modo uma multiplicidade infinita de impossibilidades.

PALAVRAS CHAVE: Sara Ramos, arte, tradução

ABSTRACT: Where to start when reading/seeing the work of Sara Ramos? I wish to start from the devices of discourse and knowledge, as well as subjective perceptions, with the intention of operating on some translation possibilities. Also, I like the idea of seeking a possibility of understanding her work through dialogues with my own artistic work. Such a challenge is to assume I am walking with her - and putting me to the test - on a threshold of poetic transmutation or, as Benjamin would say, betrayal. Although the concept of translation is inscribed in a rational inheritance that seeks to establish a kind of order of chaos, before being a creator a translator is an imaginative being who interprets in his own way an endless multiplicity of impossibilities.

KEYWORDS: Sara Ramos, art, translation

\footnotetext{
*Ana Paula Sabiá é artista visual, fotógrafa e pesquisadora. Doutoranda em Artes Visuais pela Universidade do Estado de Santa Catarina (UDESC), na linha Ensino das Artes Visuais. Mestra em Psicologia Social pela Universidade Federal de Santa Catarina (UFSC). Licenciada em Educação Artística com habilitação em Artes Plásticas, pela Fundação Armando Álvares Penteado (FAAP).
} 


\section{Introdução}

Pouco sei dos ensinamentos cristãos apesar de ter sido batizada na Igreja católica. Nunca li a Bíblia mas conheço por relatos algumas passagens que me despertam curiosidades como, por exemplo, a criação do ser humano. De acordo o livro sagrado em Gênesis': O Senhor Deus formou, pois, o homem do barro da terra, e inspirou-lhe nas narinas um sopro de vida e o homem se tornou um ser vivente. ${ }^{2}$

A mistura de dois primitivos ingredientes - água e terra - e um certo sopro divino criou, incorporou e animou algo/alguém que, a priori, parecia ser improvável possibilidade. Um ser humano vivente, pensante e sentimental que seria, então, ele/a próprio senhor/a de suas escolhas e destino.

Considerando que, também nós seres humanos, temos a criatividade, a espontaneidade e o desejo, a possibilidade da alegria apesar da certeza de mortalidade, o cultivo da solidariedade apesar dos infortúnios, a magia de gerar a vida, a crença na vida e no amor apesar das injustiças... somos divinos! Somos criadores de vidas, sentimentos e materializações de seres, sejam pertencentes à raça humana ou aqueles que se inscrevem nas esferas artísticas.

Sim, pois a arte é animada como qualquer ser vivente. Concebida em circunstancias ideais para sua realização, possui uma biografia, uma trajetória histórica, social e cultural que dialoga com a vida fluida e efêmera dos seres humanos. No entanto, a arte tem a possibilidade da imortalidade: nasce e renasce sempre aos que estiverem dispostos à confrontá-la.

Sara Ramos artista é o ser vivente que a partir do barro cria outros seres viventes e imortais. Seu sopro divino individualiza cada uma de suas criaturas e confere-lhes vida autônoma. E, tendo em vista a multiplicidade de seu estilo escultórico, a incessante pesquisa na modelagem, suas experimentações e amálgamas com outros materiais, a leveza no recomeçar outro assunto e argumento, não me surpreenderia se - após o árduo trabalho cerâmico - por acaso a ouvisse dizer "do pó vieste e ao pó retornarás".

Tal fato seria, ao meu ver, uma espécie de fala da Sara consigo mesma, genuína em sua autoconfiança, satisfeita de si em fenômeno que percebemos a partir de sua trajetória artística: livre de fórmulas, padrões ou receitas, mirando o horizonte futuro em eterno recomeço criativo, palpável e essencial tanto quanto terra e água. E ar nos pulmões. 


\section{A criação do mundo}

Sara Ramos é, nesse sentido, a deusa criadora de seu povoado e infinito universo. Com o barro primitivo e acolhedor manuseia plasticamente um porvir, um devir, uma possibilidade futura. Confere-lhe maleabilidade na mesma medida em que o forma e desenforma. Empresta-Ihe sua temperatura corporal à massa fria através de suas mãos hospitaleiras. Deleita-se na experiência cinestésica, tátil e sensual de amassar, esticar, espremer, socar e modelar a massa ainda desforme provocando sentidos e sentimentos. Seu corpo inteiro dedica-se a construção de outro corpo formado de cheios e vazios, volumes e simetrias, dentro-fora, lisuras e texturas. Brinca com tamanhos e medidas, espessuras e transparências, presenças de cores ou suas ausências, concretudes e abstracionismos. Sopra seus sonhos em cada sua criatura e as coloca à prova de si e do mundo em atitude crucial: o fogo, em sua alta temperatura, para a queima da argila.

Conheci a artista e seu trabalho na mesma ocasião ${ }^{3}$ em rara oportunidade de ser apresentada à criadora e criatura. Minha empatia com a criadora, em seu genuíno e aprazível relato a respeito de seu processo criativo e de suas referências e arquivos pessoais me emocionaram quase tanto sua extensa obra. Aquelas espantosas - fálicas e vaginais - fauna e flora cerâmicas; as refeições luxuosas apesar de serem feitas todas do mesmo barro; órgãos humanos sem corpos ou corpos sem órgãos ${ }^{4}$; os seres humaninhos enquadrados em suas celas envidraçadas, todos sem rostos e assexuados... eram visões oníricas para mim. Mais do que isso, se aproximavam de qualquer imagem profundamente enraizada desde tempos imemoriais em nosso inconsciente, como defendia Jung ${ }^{5}$ a respeito dos arquétipos. ${ }^{6}$

Me reconheci no mundo de Sara Ramos; não como se fosse minha auto-imagem refletida nas águas-espelho onde se perdeu Narciso, mas como uma exploradora inesperada da floresta alucinógena de Avatar ${ }^{7}$. Era possível que após anos morando nessa ilha de Santa Catarina eu ainda não tivesse conhecido o mundo fantástico de Sara Ramos? Em que caverna estivera? Como podia essa criadora afável e sorridente, generosa e jubilosa gestar e parir criaturas assim, tanto extraordinárias quanto afrontosas?

Instigada e provocada, curiosa de outras minúcias artísticas me atentei em ouvir a respeito de suas fontes de inspiração a partir de seus arquivos. O que teríamos em comum, Sara Ramos e eu, em nossos sistemas de enunciados que reverberava seu mundo no meu? O óbvio fato de sermos artistas mulheres não explica nenhuma coincidência. Ou será que explica? 
A certeza de que somos seres sociais agentes transformadores do espaço-tempo em que vivemos, inseridos/as em dado momento e círculo cultural pode justificar muita coisa nas aproximações e inquietações artísticas, ainda mais vivendo, supostamente, em uma mundo comunicacional interconectado e arquivado. Contudo, nos diferimos por inúmeras outras sutilezas e complexidades pelas quais acreditamos, ainda, sermos indivíduos incondicionalmente insubstituíveis.

Existir é radicalmente diverso de sentir-se vivo(a). A icônica frase ${ }^{8}$ de Descartes, que funda o modelo de racionalidade empírica acima de todas as outras formas de validação do conhecimento, é calcada na supervalorização da razão que, hipoteticamente, garante o conhecimento verdadeiro, absoluto e inquestionável. Passados séculos, ainda que motivados pelos avanços, continuamos sendo formatados desde tenra idade pelo pensamento cartesiano na construção de um modelo de verdade indubitável.

Aventurar-se nos campos dos saberes, lugar onde se constituem dispositivos, é sempre escolher a trilha a seguir nas bifurcações: desde aquelas que nos maravilham e nos faz querer morar e demorar ${ }^{9}$ no prazer do conhecer e nos perder por paisagens desconhecidas; como também pode-se percorrer o caminho mais fácil e sem surpresas. Muitos preferem optar pela segunda alternativa.

Concomitantemente, os saberes - esses tais conhecimentos legitimados e empiricamente comprovados - também constituem uma verdade que nos sujeita ${ }^{10}$. Nos delimita em nossas possibilidades do devir ${ }^{11}$. Nos aprisiona em uma identidade fixa e inflexível. Oportunamente, a arte é um saber libertador e imaterial. É um saber que não qualifica, não quantifica e não pode ser mensurado, pois provém e afirma subjetivações.

O lugar da arte não pode ser antecipado pois, sendo esta um engenhoso sistema de enunciados como tal comporta desmesuras. Foucault discorre ${ }^{12}$ sobre o conceito de arquivo tal como campo de enunciados, sendo que estes são considerados inantecipáveis, pois todo arquivo é movente. Sendo assim, criar/fazer arte pressupõe lançar mão do arquivo e ir além, mover-se com ele, ultrapassar um sujeito sujeitado e permitir aflorar o sujeito subjetivado, este sim, consciente da potência de seu próprio e intransferível arquivo.

Enunciado difere de enunciação. O primeiro pertence à ordem dos raros, das singularidades e imparidades artísticas. Já o segundo comporta um falar sobre, sugere um capital que se 
acumula com o tempo. O enunciado do artista entra em um campo onde se constitui saberes e práticas, conjunto de falas e textos, táticas e estratégias que aparecem no arquivo. E fomenta sua vontade de saber, seu desejo de (re)descoberta e (des)construção deste e outros mundos.

\section{Hibridismo entre espécimes: Sara Ramos e Ana Sabiá}

Sara Ramos, com sua arte, remexe nas vísceras pegajosas de Gaia ${ }^{13}$ com zelo maternal e euforia apaixonada. O prazer erótico se anuncia em suas criaturas arredondadas ou pontiagudas; tessituras irregulares - tanto quanto as polidas e reluzentes peças esmaltadas - invocam fetiche. Um amor fraternal, palpável na argila, modela em três dimensões aquilo que nos iguala como mortais: sangue, órgãos, sonhos...

De onde iniciar a ver/ler a obra de Sara? Desejo partir dos dispositivos do discurso e do saber, além de minhas percepções subjetivas, com o intuito de operar em algumas possibilidades de tradução. Além disso, me agrada a ideia de buscar uma viabilidade de compreender sua obra a partir de diálogos com a minha própria fatura artística. Tal desafio é assumir caminhar junto dela - e me por à prova - em um limiar de transmutação poética ou, como diria Benjamim, traição ${ }^{14}$. Buscarei traduzir pontos de encontros/diálogos presentes em nossas obras a partir de um discurso alegórico e aberto, evitando suposta cópia ou representação.

Descobrir o mundo e descobrir-se no mundo é uma eterna tradução. Pensar é buscar traduzir a experiência vivida, assim como escrever e falar é uma tentativa de tradução da experiência pensada. Um a priori é nossa própria presença na experiência em si. Nesse sentido, apesar de o conceito de tradução inscrever-se em uma herança racional que pretende estabelecer uma espécie qualquer de ordem ao caos, um tradutor é antes ser criador, ser imaginativo que interpreta a seu modo uma multiplicidade infinita de impossibilidades. Traduzir é percorrer nos limiares de abismos inexoráveis, pois do pensamento plástico ao teórico, do ver ao dizer, do sonho ao relato, tudo o que temos é tradução.

Fazer arte é um dos modos de traduzir, mediar e dialogar a experiência vivida individualmente naquela coletiva, que por sua vez será tanto múltipla e diversa quanto forem as muitas verdades dos muitos sujeitos pensantes e viventes dispostos a pôr-se em relação a (algo ou alguém). Relação essa que consagra a experiência do vivido é a base que abastece e nutre 
um arquivo pessoal. Todo sujeito, por meio de competências singulares e em esferas diversificadas, é um tradutor de seu próprio arquivo e, especificamente o/a artista, ainda que seja um consciente tradutor - também assim! -nunca alcança o original.

O/A artista vive do desejo de manter-se permeável ao seu próprio arquivo individual-coletivo no intuito de fecundar-se, gestar e parir suas verdades artísticas. O arquivo de um/a artista, seja da ordem material ou sentimental, é fonte inesgotável de ideias, ideais atingidos ou inatingíveis e fonte de retroalimentação artística.

Inicio minha exploração particular a partir das aproximações entre Sara e eu. Ou melhor, da relação inscrita em alguns de nossos trabalhos. Defino, desde já, que a partir deste ponto, nesse sub-capítulo, crio uma espécie de manobra metodológica na qual escreverei em terceira pessoa, na tentativa de propor um olhar distanciado de minha própria fatura colocando as imagens das obras ${ }^{15}$ lado a lado ao articular enunciados e algumas possíveis traduções.

Genesis Totêmico e Amor / são trabalhos que se diferem na categoria plástica, no entanto tem seus pontos de interlocução. Sara modela uma esfera-mundo/ esfera-últero/ esfera-óvulo/ esfera-gênesis, célula primeira da inicial espécie de seu universo. E, não satisfeita de seu feito, infringe em seu globo enigmático uma profunda fenda que, por sua vez, irrompe em outras direções como afluentes de um rio. É A origem do mundo de Sara, também em diálogo com a icônica pintura de Gustave Courbet: uma sensual vulva entreaberta à espera do desejo do olhar e da imaginação.

Em Amor I, Ana Sabiá fotografa o feito de uma íntima performance que problematiza a experiência de recuperar algo que já deixou de ser na fatalidade do tempo. O frágil mundo-ovo que partiu-se não retrocede à superfície lisa e hermética, assim como a vida que ali se aninhava não poderá - nunca mais - retornar ao ovo-útero. A sutura é uma evidente tentativa fracassada de reatar os estilhaços.

O rebentar de um corpo concreto é um reflexo do nascimento de algo inominável insinuado em ambos trabalhos. Pode-se falar em seres, fauna e flora mas desconfio que isso seria apenas o visível. Há de ter rompido o invólucro - do globo de Sara e dos ovos de Ana - algo que está além da consciência, se infiltra no âmbito da magia, tece proposições alquímicas e nos conecta todos em algum lugar ínfimo, celular e íntimo de ser vivo. 



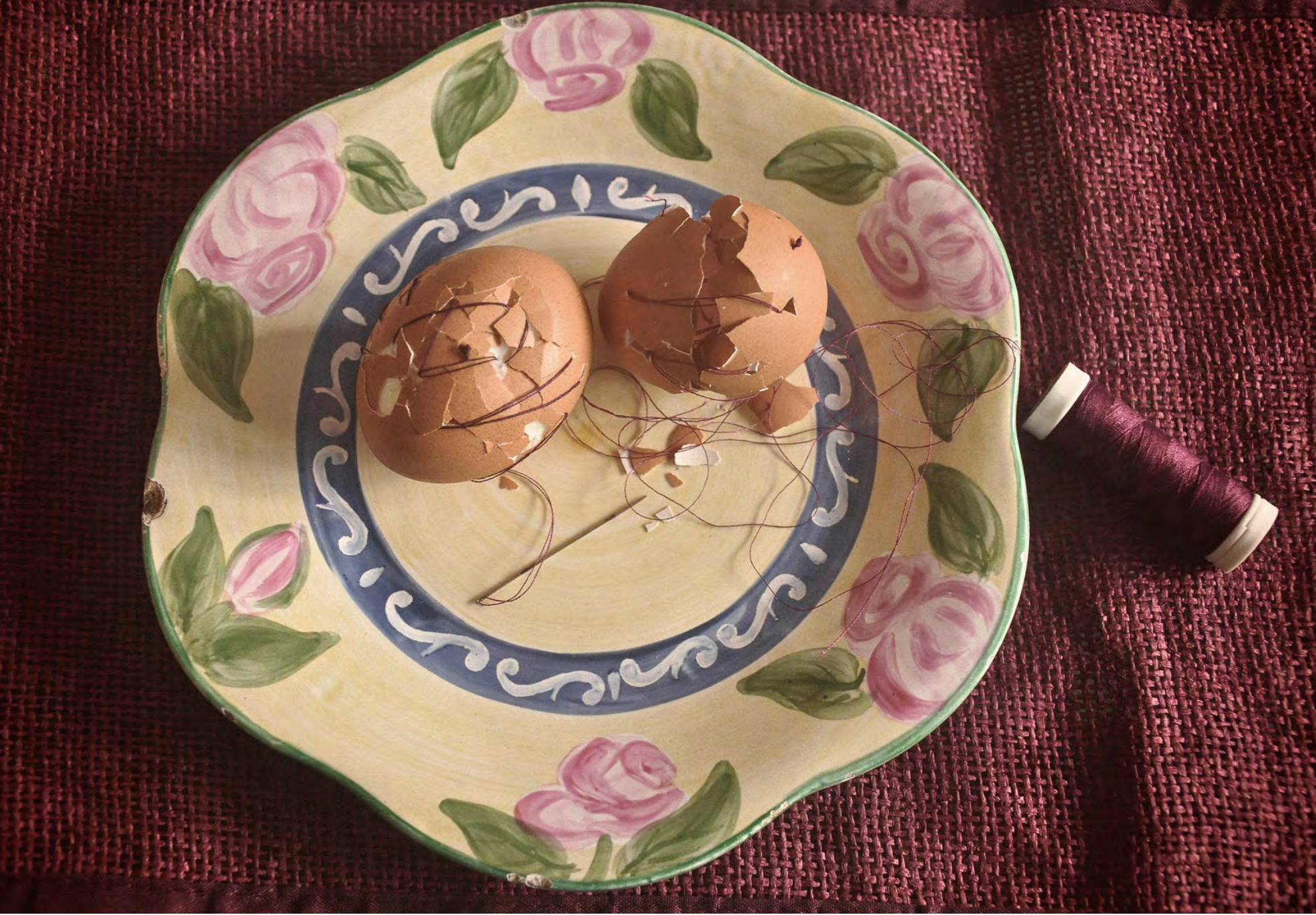

Amor I (da série "Do porão ao sótão")

Ana Sabiá

Fotografia Digital, 2015 
Em ENGOLIdores Fálicos Sara novamente reverencia a força geradora e descomunal da ubíqua Mãe-Terra a partir de seu material originário e, em ação serial, espreme, alisa e dá formas à milhares de pequenos órgãos hermafroditas. O próprio título do trabalho nomeia a androginia sexual limítrofe entre a vagina - como receptáculo engolidor - e o falo. O trabalho se complementa com a exposição desses órgãos em asséptica clausura transparente: grupos empilhados indiferentes entre si, multidão aprisionada sem identificação à espera de seu derradeiro momento de dar-se a ver. Ao lado deste coletivo, outra caixinha envidraçada singulariza uma única peça, feita do mesmo barro e proporções que as demais mas, que ali, isolada e misteriosa, atrai nosso olhar mais minucioso.

Em Matrioshka I Ana brinca com a seriação na temática sexual a partir de cinco mariscos perfilados e crus, desprotegidos de suas cascas rígidas e, ainda assim, receptivos e abertos.

Tais moluscos que, visualmente, assemelham-se a vaginas humanas, estão perfilados um ao lado do outro do maior ao menor como que formando gerações pertencentes ao mesmo clã. O título do trabalho faz menção a Matrioshka ${ }^{16}$ como referencia de brinquedo lúdico de encaixe e a relação com a maternidade e suas heranças genéticas e acondicionamentos sócio-culturais que nomeiam a instituição familiar e os "ensinamentos" de ser mulher.

Sara e Ana produzem colecionáveis, problematizam o acúmulo e o substituível, discursam nas esferas individuais e coletivas a partir da série. Enfrentam instituições e a moral vigente que dita regras rígidas acerca da família e do sangue como enunciado de poder, questionam os gêneros a partir dos atravessamentos sexuais e evidenciam uma temática estratégica sobre a potência do feminino na arte. Apesar dos assujeitamentos impostos às mulheres, sejam eles íntimos ou plurais, ENGOLImos nossas dores ${ }^{17}$, vomitamos nossas resistências e seguimos às lutas.

O par seguinte comunga a comida e o ato de comer em surrealismo inscrito na transmutação de uma forma em outra em antropofagia plástica. Em Você tem fome de que? Sara põe a mão na massa, tanto para criar a forma no barro - misturando terra e água como ingredientes elementares - quanto para fermentar o alimento universal, com suposta água e farinha, que modela a dádiva do pão. Do forno artístico de Sara saem especialidades como os croissants-casulos, donuts porcelânicos, espaguetes-novelos, corações-vulcânicos, bolos-dentados, ostras-nervurosas, chocolates-pedras e queijos-dinossáuricos. Comida e sexo são complexas 

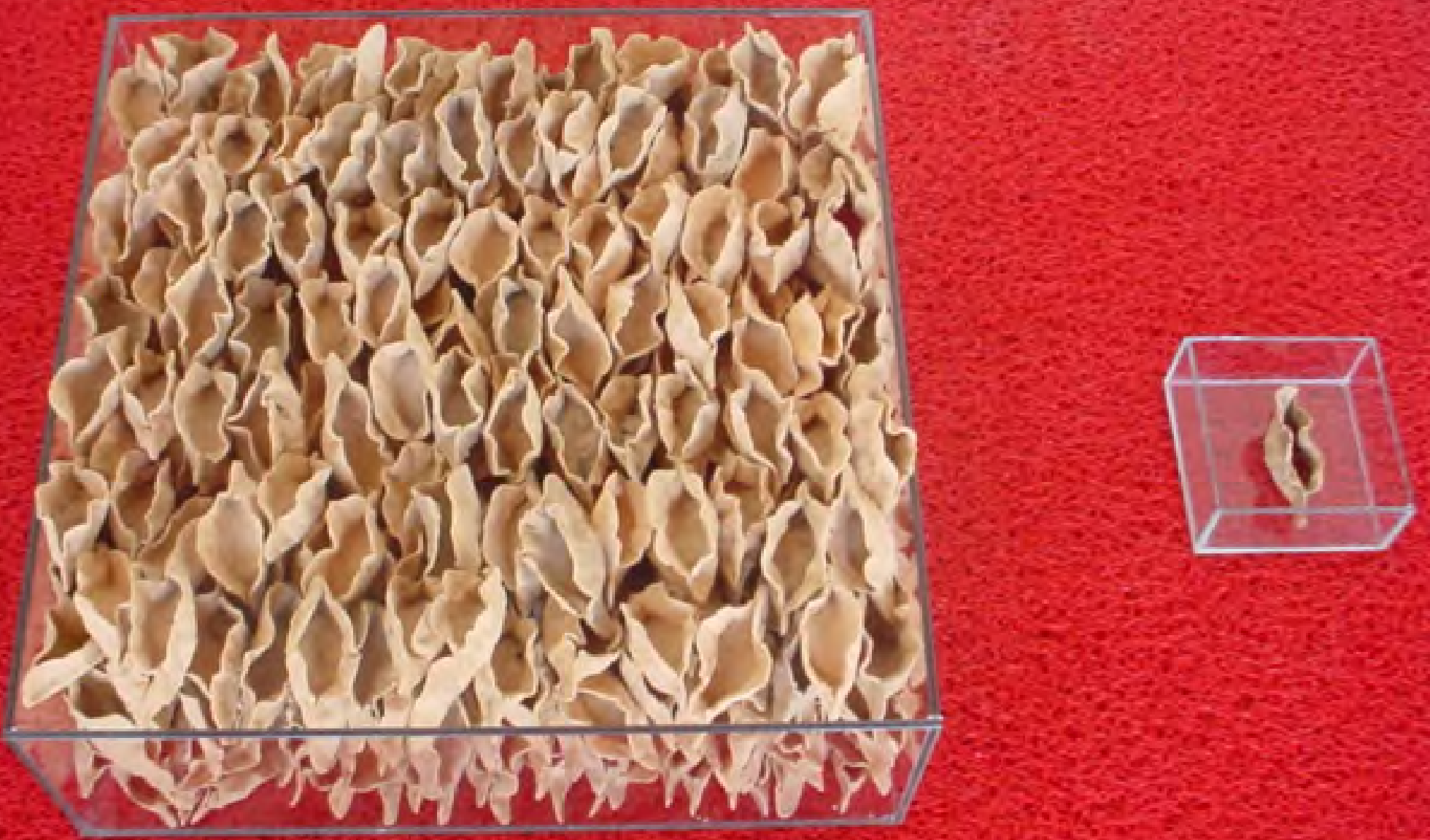

ENGOLIdores Fálicos Cerâmica

Sara Ramos, 2005 

tessituras entre si, ambos são alimentos do corpo e da alma. O seio que amamenta é também o que desperta os desejos eróticos. Os alimentos modelados por Sara são aparentemente saborosos e prontos ao paladar se não fosse sua origem pétrea. A ausência das cores e a esmaltação vitrificada intriga os demais sentidos e provoca a tentação ao toque. Os pratos escuros, rugosos e fósseis exibem as iguarias gastronômicas em precisão estética dos mais renomados chefs. A santa-ceia está posta. Quem serão os convidados à essa mesa?

Roedor, de Ana Sabiá, é uma das imagens que integram a série Do porão ao sótão que propõe tratar de temáticas como efemeridade, memória e desejo da perpetuação, ou de uma tal preservação, daquilo que já não pode mais ser: uma vida que flui e não volta, um amor que se esvai, sonhos que perderam a validade ou não foram concretizados. Os acontecimentos banais que permeiam a vida e sua finitude são fontes de inesgotável beleza e gravidade se aptos à percebê-los. O microcosmo doméstico carrega a complexidade macro a partir das relações, percepções e posicionamentos ali inscritos. A imagem afirma uma vida passada, um órgão desconectado do corpo, uma anterior mandíbula nervosa de algum animal livre. Agora jaz dentes inertes, fotografados por um ângulo que os transformam em um outro ser. Também aqui foi possível a transformação da água em vinho pelo milagre da imaginação e da arte.

Em Inventario do Feminino Sara dispõe sobre uma almofada uma coleção de objetos de uso pessoal de uma singular mulher. Os objetos banais expõe algumas características dessa insólita proprietária burguesa: sapatos e bolsa de grife, um chaveiro com chaves do automóvel, um batom usado com embalagem de luxo, um pequeno espelho, lenço de linho bordado a mão, um coração kitsch (que pode ser a caixinha que acondiciona seu diafragma), um vibrador elétrico, uma fotografia B/W ${ }^{18}$ antiga com o retrato de um/a bebê, uma chupeta com aspecto de modelo antigo e a almofada decorativa em estilo Luis $X V^{19}$. Essa listagem de bens de consumo, que a primeira vista não desperta maiores curiosidades, impacta profundamente ao sabermos a origem de sua fabricação: tudo materializado em argila! Da maciez do lenço à borracha do vibrador, da delicadeza da costura da almofada às ranhuras das chaves do carro... tudo cerâmica! E então, conscientes de que fomos enganados por Sara, traídos em nosso pré-conceito, nos maravilhamos e nos abrimos às interpretações. Aquele inventario, agrupamento de bens, herança material semi-nova, já não servirá a mais ninguém! Do pó veio e ao pó retornará. A herdeira Cinderella não poderá calçar os scapins pois seus saltos se 


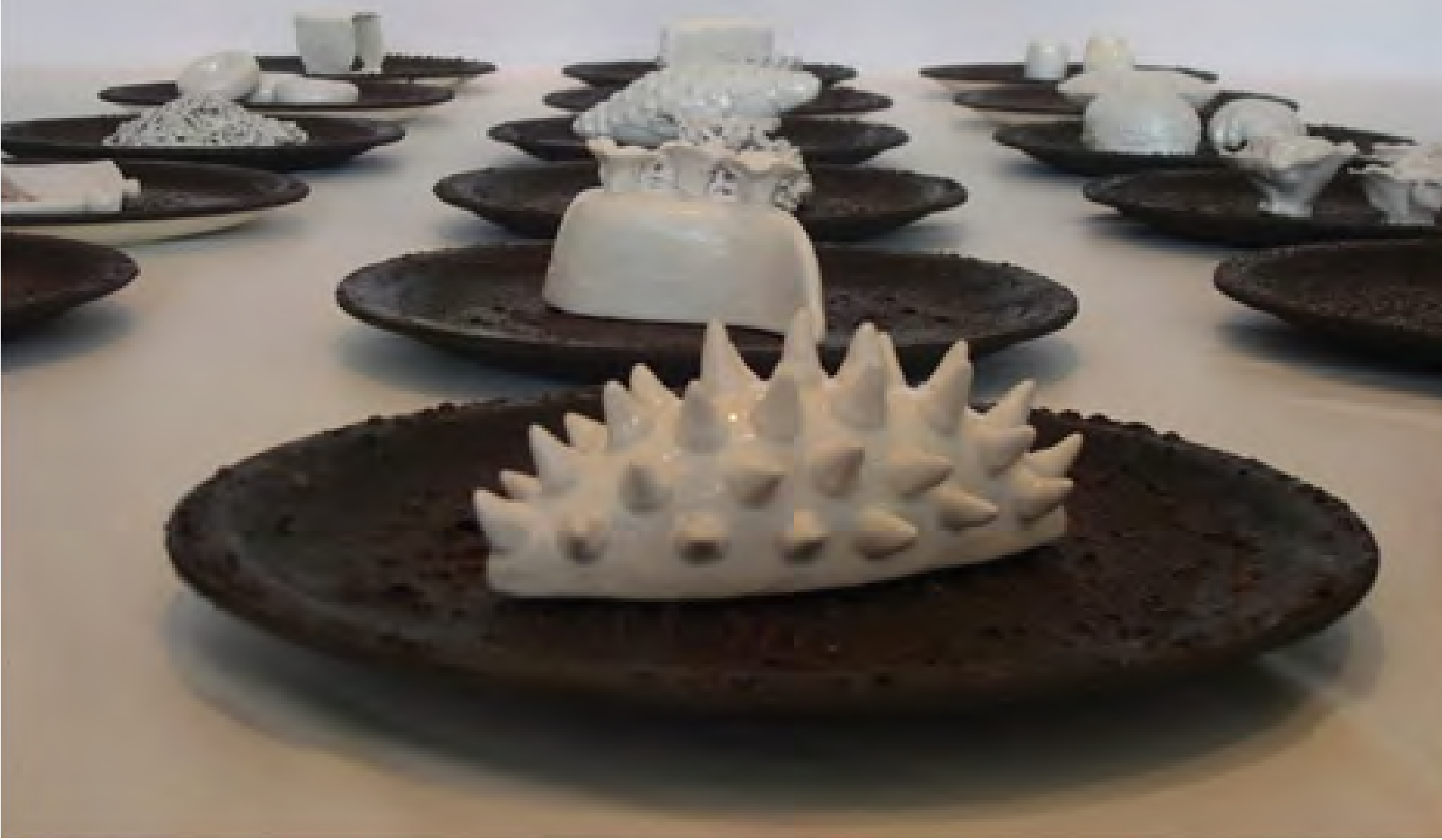

Você tem fome de que?

Sara Ramos

Cerâmica, 2010 


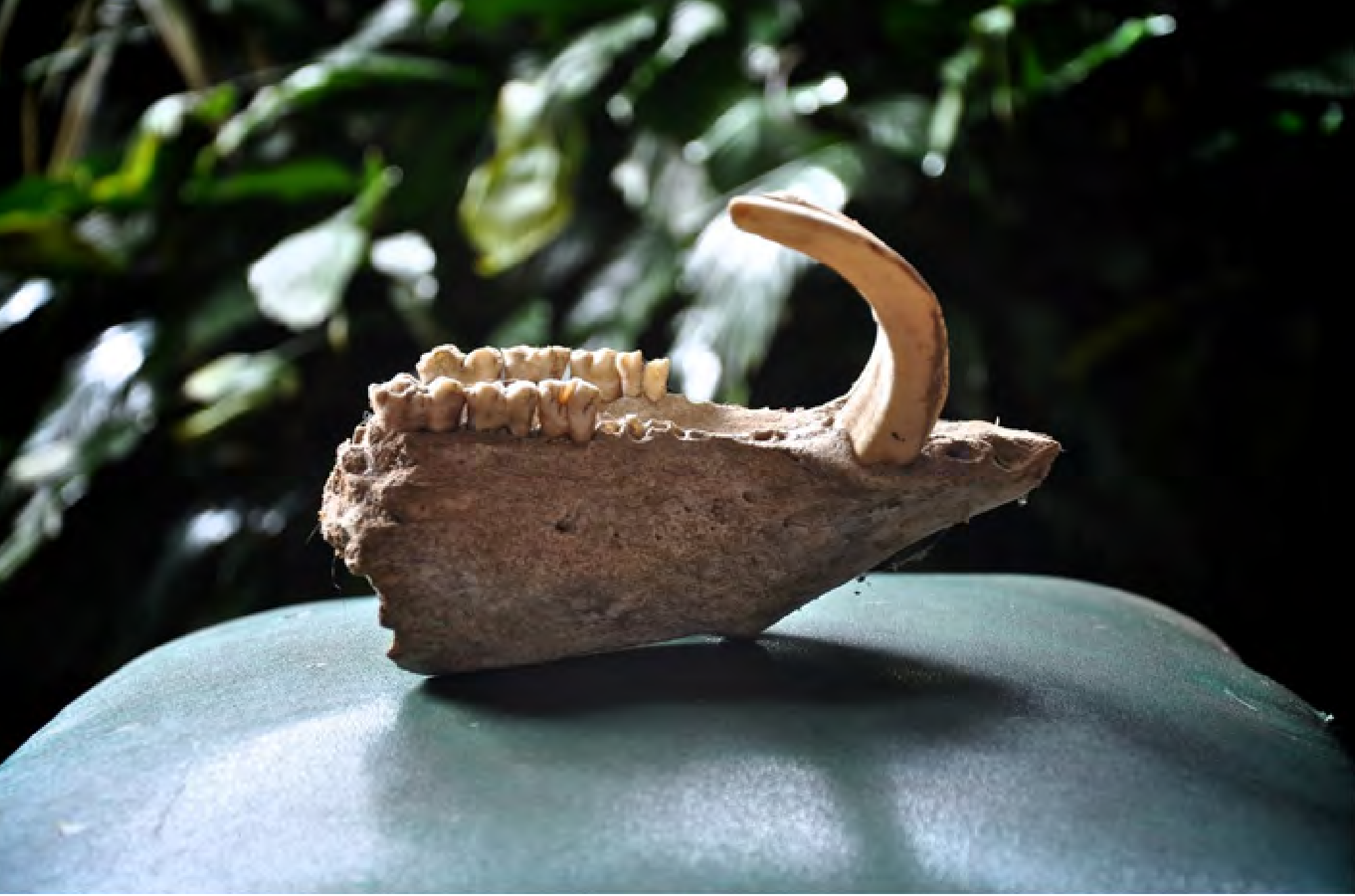

Roedor (da série "Do porão ao sótão")

Ana Sabiá

Fotografia Digital, 2017 
esfacelarão ao primeiro passo. Assim como os demais itens ali dispostos para impressionar mas, sabendo de sua origem, impressionam pela sua inutilidade. Contudo, a serventia está na proposição à reflexão. Sara consegue superar-se escultóricamente em assombrosa fidedignidade com os objetos apresentados no entanto, sua maior façanha é conseguir dar seu "tapa com luva de pelica" em nosso pré-juízo que titubeia acolher o inesperado, ou o faz de modo superficial, a partir das aparências enganosas.

Em Bela, recata e "do lar" Ana reage artisticamente à polêmica manchete veiculada por uma revista brasileira ${ }^{20}$ e propõe contextualizar tais supostos adjetivos dentro das intrincadas tecnologias de poder que perpassam as políticas de controle sociais ${ }^{21}$. Trata-se de três cabeças em cera moldada, peças de ex-voto ${ }^{22}$ com sua conhecida carga religiosa, representando agradecimentos dos fiéis por graças e curas alcançadas. Contudo, cada cabeça difere-se entre si por efeito de alguns orifícios, feitos propositalmente, nos olhos, na boca e nos ouvidos. A provocação deste ato evoca o folclore japonês dos Três macacos sábios ${ }^{23}$ que, aliados ao título do trabalho, evidencia o sarcasmo na crítica de pensar a "boa" mulher: aquela que não vê, não fala e não escuta. Tal qual uma boneca erótica.

Atualmente, posicionar-se com ideais feministas é partir do princípio que ser livre também significa negar estereótipos que não compartilhamos ou nos ferem, e não aceitar mais o assujeitamento por qualquer demanda externa em nome de um determinado ideal de beleza, de comportamento e de ideias. É atentar aos discursos enviesados, que mascarados pela sedução midiática, pretende homogeneizar as multiplicidades de ser mulher na propagação de controle e desnivelamento de gêneros. Assumir essa posição ética e humana é tomar parte do fazer política, ainda que se esteja no âmbito doméstico. ${ }^{24}$

Ambos os trabalhos tematizam um feminino que não se molda nos padrões assujeitantes. As cabeças de cera, apesar da aparente rigidez, derretem-se facilmente em qualquer fonte de calor. Os utilitários luxuosos não podem ser empregados para seu derradeiro fim: esfacelam-se em poeira e perdem seu status. O feminino explorado por Sara e Ana ampliam a condição da mulher nos elementos ali delimitados e abrem problematizações para além do masculino/ feminino: dialogam com o sujeito nas suas múltiplas escolhas, sejam estas permeadas pelo sexo ou não. 


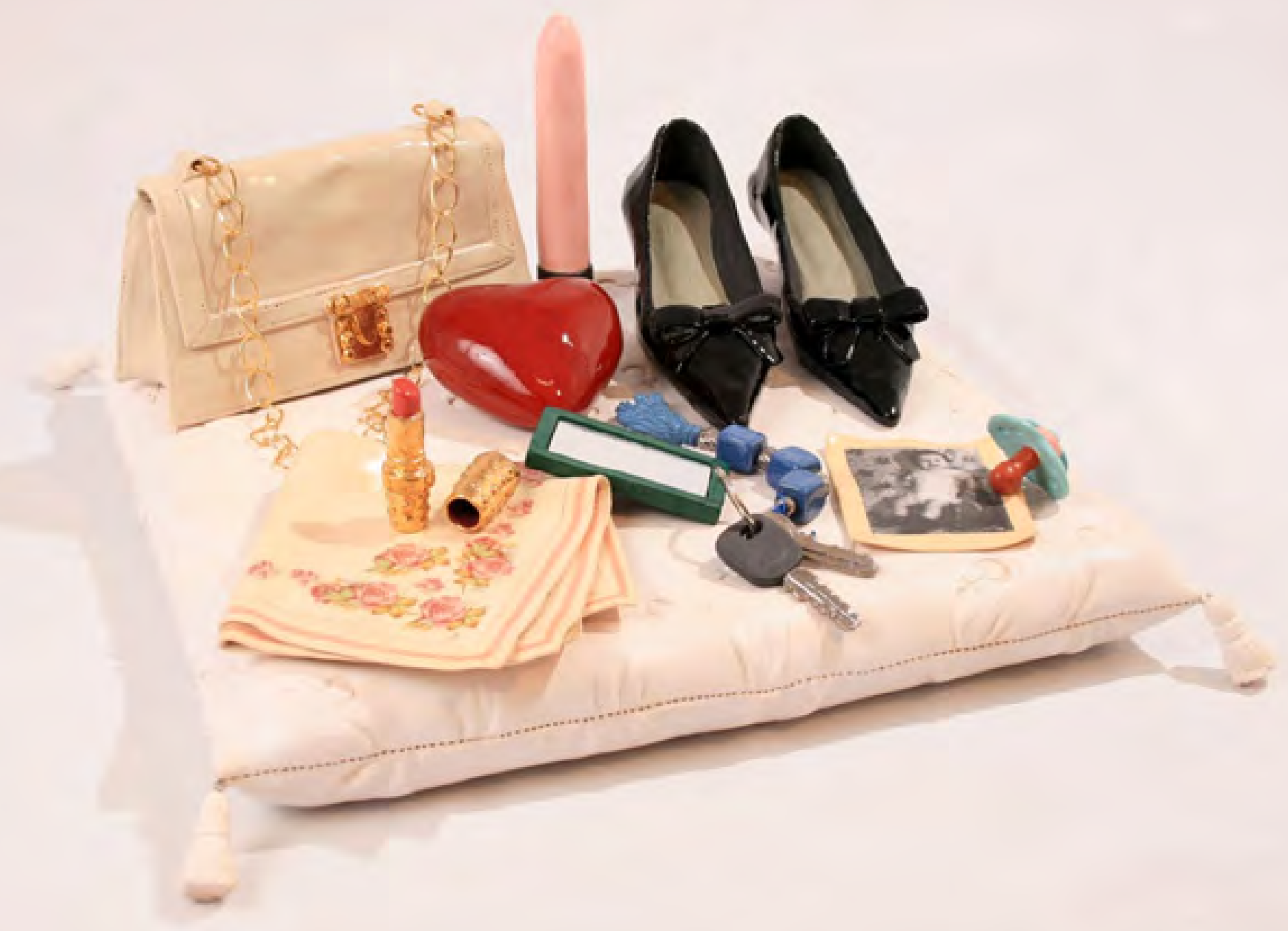

Inventario do Feminino

Sara Ramos

Cerâmica, 2008 


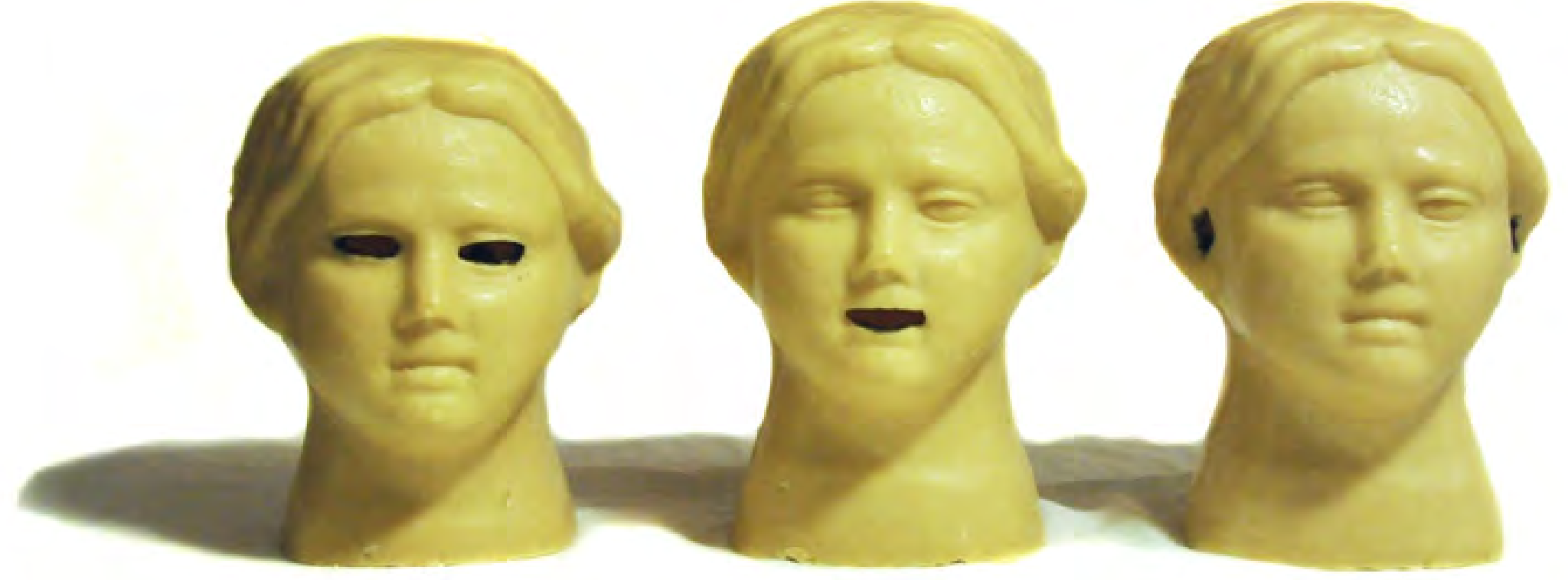

Bela, Recatada e "do lar", I

Ana Sabiá objeto

Cera moldada, 2016 
Os trabalhos seguintes Íntimo Plural e Líquido Amniótico retratam seres cativos em seus espaços conhecidos. Sara acomoda um coletivo de seres humaninhos cada qual em sua individual caixinha translúcida. Esse edifício envidraçado dialoga com nossa vida contemporânea: a comunicação em rede que isola as experiências atrás de um monitor de celular ou computador, as intimidades da vida privada expostas ao alcance de qualquer um apenas com um click em diversas redes sociais, viver a partir da profética sentença de Andy Warhol onde o, então, futuro é agora e todos temos o direito aos nossos "quinze minutos de fama". Celebridades fabricadas para o consumo veloz como se fossem mercadorias perecíveis. A ilusória liberdade de ser o que se quer em confronto com as vigilâncias tecnológicas: da escolha do filme na poltrona de casa assistindo Netflix à compra de medicamento com cartão de crédito e emissão de nota fiscal na farmácia do bairro distante de outro país. Tudo é vitrine e todos rastreados.

Ana se retrata com a cabeça quase totalmente imersa em uma vasilha vítrea transbordante de água que, por sua vez, esta apoiada sobre outra superfície lisa como vidro jateado, sugerindo uma bandeja. Essa água é entitulada pelo líquido a que todos já estivemos imersos dentro do útero. Líquido primordial que confere proteção ao embrião contra choques mecânicos e térmicos além de proteger futuras penetrações masculinas ${ }^{25}$, envolve uma retratada inativa sugerindo calmaria - pelo bem estar subaquático - ou morte por afogamento. O espectador da imagem é quem decide.

Para finalizar os diálogos entre Sara Ramos e Ana Sabiá estão seus trabalhos Oferenda e A insustentável leveza do ser. Sara modela em argila inúmeras pequenas vasilhas irregulares, cada qual contendo em seu interior uma substância vermelha como sangue. Se é líquido ou menos pouco importa, mas o conjunto dessas meia-esferas, partidas em metades, ganha inteireza no corpo da instalação. Evoca nossa ancestralidade a partir do barro e do sangue, reverencia espíritos que já corporificaram algo ou alguém, reconhece nossa mortalidade apesar da fé. Brindamos ao passado e presente e oferendamo-nos um futuro promissor.

Ana problematiza um frágil e descomposto "corpo" estilhaçado em cacos cortantes que se formatam sob a finíssima meia em reconhecível silhueta feminina. Uma cadavérica mulher se faz insinuar a partir de sua geografia corpórea em reivindicação urgente e emergente que transparece a temática da violência. A potência deste corpo se dá com a soma dos milhares de caquinhos irremediáveis, cada qual com sua importância para volumizar e legitimar discursos e ações. 


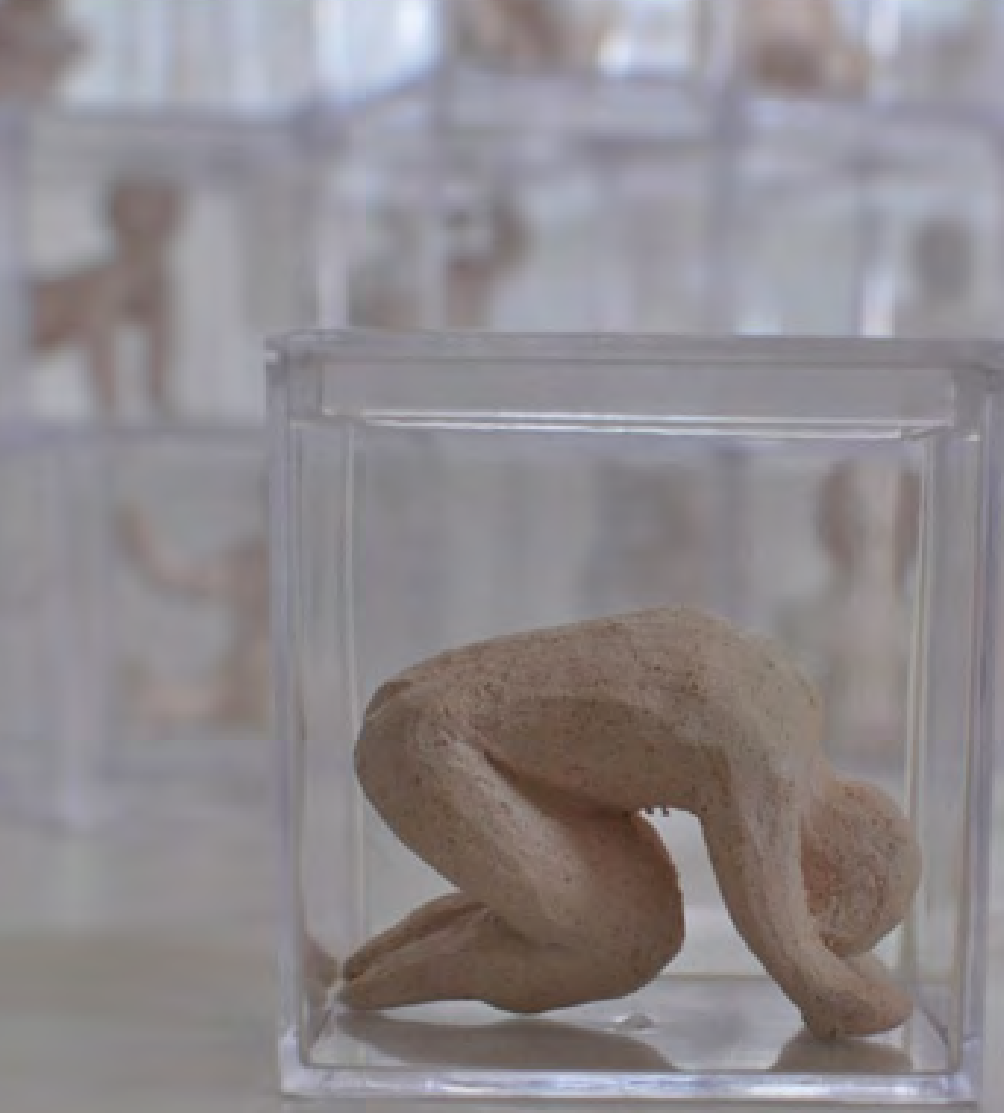

Intimo Plural

Sara Ramos

Instalação Cerâmica, 2013 


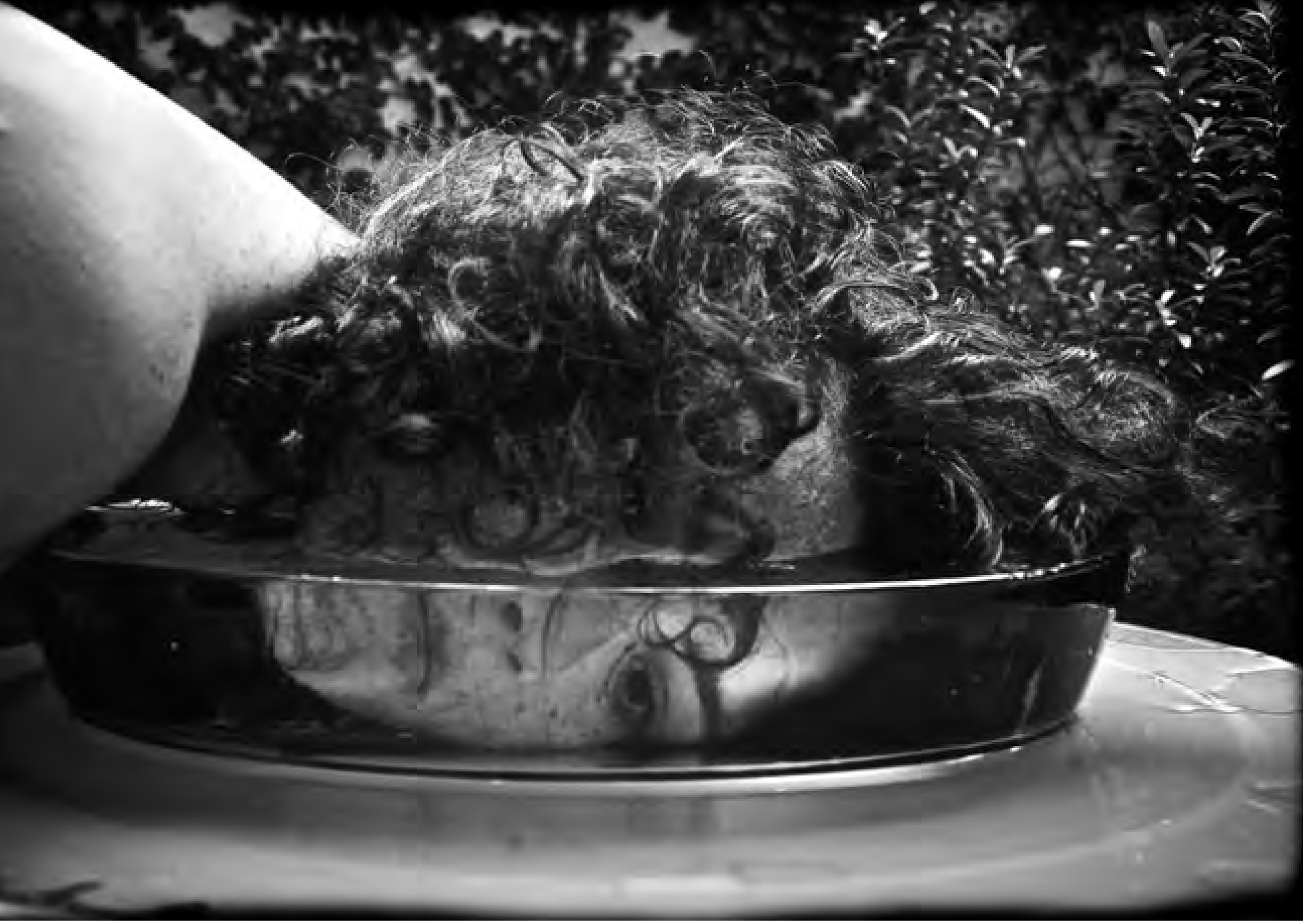

Líquido Amniótico, I

Ana Sabiá

Fotografia Digital, 2016 
Tanto um trabalho quanto outro anuncia a resistência, a oferenda pela dádiva da vida e o brinde aos recomeços. Afirma a existência das lutas diárias dentro e fora do âmbito doméstico, individual e coletivo dia-a-dia. Ainda que houve significativas conquistas pelas e para mulheres é a constância que as legitima. Levantam-se dos cacos colando os milhões de pedaços em que se partiram. E seguem.

\section{Arquivamentos nas nuvens}

O arquivo é a um só tempo tradição e esquecimento, circunscreve o lugar da raridade, mas também o da regularidade que são aqueles elementos que constituem a série, onde apreendemos pedaços que vamos compondo uma espécie de constelação ${ }^{26}$.

Nossa cultura é a base de nosso arquivo coletivo e nossas subjetivações a partir dele formam nossas relíquias íntimas, feito de coisas materiais e afetivas. Arquivos constituem-se em um sistema de enunciados indefinido e incorpóreo como iCloud ${ }^{27}$, além do arquivamento material também o constituem percepções e sensibilidades. ${ }^{28} \mathrm{O}$ arquivo é uma desmesura sempre dada por algo que está aquém e além das coisas; estão sujeitos a desdobramentos, construções e pertencem à ordem do processo e não da priori.

O/A artista articula seus arquivos de maneira interdisciplinar, não valendo apenas de uma competência e disciplinas, mas imbricadas entre si. A arquia é o estado de arquivo de artista onde encontram-se arquifenômenos, arquidesenhos, arquipercepções, equipotência... Nascem em um estado de confusão babélica, deixam rastros que supõe origens desconhecidas, denotam um campo indiviso, primordial que desde esteve lá, assombra-nos de modo espectral e nos atravessa ao longo do tempo intermitentemente marcando uma trajetória/retrospectiva de artista. É o arquivo imaterial das afecções.

Em Gramatologia, Derrida propõe a partir das artes espaciais pensar o que não se vê, essa extra-parte que comungam as artes em geral, onde engendram rastros e devires. Daí me coloco como a outra artista para pensar Sara Ramos, pois o autor defende que para pensar algo precisamos confrontar com outro algo.

Minha tradução da obra de Sara foi a partir dos diálogos com minha própria obra, em atitude que busquei como um modo de desacomodar-me: tanto para ampliar os panoramas de 


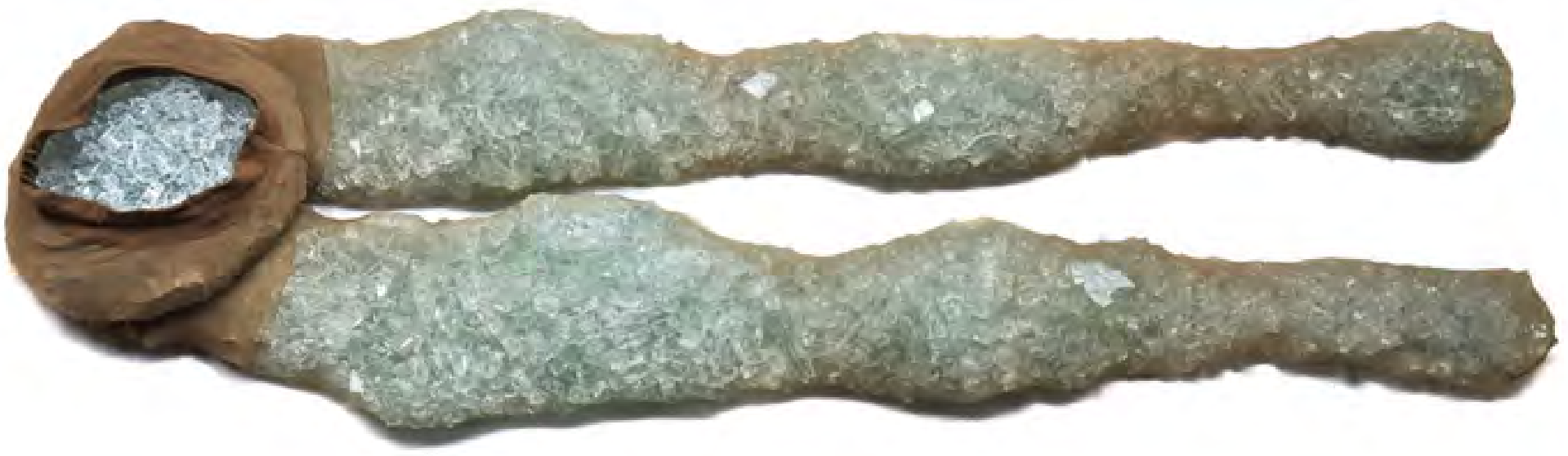

A insustentável leveza do ser

Ana Sabiá

Meia de nylon e vidro objeto e fotografia digital dimensões variadas, 2016 
exploração quanto para distanciar-me da figura do Arconte (dono da casa/dona de casa), que legitima a verdade do arquivo. Considerei ser a curadora de meu próprio Museu Imaginário²9, retirando a obra de seu contexto para construir outras relações, reconfigurando e arquitetando novos agrupamentos e - consequentemente novas significações - à medida em que olhava para as obras dispostas lado a lado. Ofereci-me aberta e imaginativa ao aproximar e relacionar as obras de Sara Ramos das minhas, propondo a criação de novas soluções, séries, linhagens, me contentando mais em seduzir do que testemunhar.

Sara com sua produção artística - e o compartilhar de seus arquivos referenciais fomentadores de suas criações - trouxe à tona alguns do meus próprios arquivos. Revirou minha memórias e estimulou meu empenho por tradução: de nós enquanto artistas mulheres, de suas espantosas obras e das minhas criações em relação às suas.

O trabalho com argila é um aprendizado amoroso consigo próprio pois, enquanto úmido, pode ser sempre refeito e consertado em ato que provavelmente contribui para o desenvolvimento da auto-estima e auto confiança. Neste ensaio fantasiei modelar amorosamente uma relação entre minha obra e a de Sara e, com esse mesmo espírito, intentei traduzir a poética da artista: Sara Ramos como Gaia, a Mãe-Terra das criaturas de terra. Sara como Gaia-Madonna constituída de terra, água, fogo e ar, sonho, sopro, leite, lágrimas, risos, sangue e a vasta fauna e flora dos sentimentos.

Artigo aceito pra publicação em dezembro de 2016.

\section{Notas}

1 Gênesis ou Génesis é o primeiro livro tanto da Bíblia Hebraica como da Bíblia cristã, antecede o Livro do Êxodo.

2 Genesis 2,7

3 Cursando a disciplina "Territorialidades Modernas e Contemporâneas", ministrada pela Prof ${ }^{a}$ Dr ${ }^{\text {a }}$. Rosangela Cherem, no Programa de Pós Graduação em Artes Visuais da Universidade do Estado de Santa Catarina (UDESC), no $2^{\circ}$ semestre de 2016.

4 Corpo sem órgãos, conceito de Antonin Artaud, que Deleuze e Guattari revisitaram e atualizaram nos célebres livros Mil Platôs e Anti-Édipo.

5 Carl Gustav Jung (1875 - 1961) foi um psiquiatra e psicoterapeuta suíço que fundou a psicologia analítica. Jung propôs e desenvolveu os conceitos da personalidade extrovertida e introvertida, arquétipos e o inconsciente coletivo. Seu trabalho tem sido influente na psiquiatria, psicologia e no estudo da religião, literatura e áreas afins (fonte: Wikipedia). 
6 Arquétipo, na Psicologia Analítica, significa a forma imaterial à qual os fenômenos psíquicos tendem a se moldar. C.G.Jung usou o termo para se referir a estruturas inatas que servem de matriz para a expressão e desenvolvimento da psique (fonte: Wikipedia).

7 Filme de fantasia lançado em 2009, dirigido por James Cameron. No exuberante mundo alienígena de Pandora vivem os Naıvi, seres que parecem ser primitivos, mas são altamente evoluídos. Como o ambiente do planeta é tóxico, foram criados os avatares, corpos biológicos controlados pela mente humana que se movimentam livremente em Pandora. Jake Sully, um ex-fuzileiro naval paralítico, volta a andar através de um avatar e se apaixona por uma Naıvi. Esta paixão leva Jake a lutar pela sobrevivência de Pandora (fonte: Wikipedia).

8 "Penso, logo, existo.", René Descartes (1596 - 1650)

9 DERRIDA, 2002

10 FOUCAULT, 1995.

11 DELEUZE, 1993.

12 FOUCAULT, M. Arqueologia do Saber, 1995.

13 Gaia, Geia ou Gé, na mitologia grega, é a Mãe-Terra, como elemento primordial e latente de uma potencialidade geradora incrível. Segundo Hesíodo, no princípio surge o Caos (o vazio) e dele nascem Gaia, Tártaro (o abismo), Eros (o amor), Érebo (as trevas) e Nix (a noite). Fonte: Wikipedia

14 Para o autor, a tarefa do tradutor, mais do que transportar é trair. Obras escolhidas, v/ / a III,. S.P.: Brasiliense, $1985-1988$.

15 As imagens dos trabalhos cerâmicos de Sara Ramos (http://www.sararamos.com.br) foram baixadas do site da artista na internet e os créditos da imagem são da própria artista, com excessão da fotografia do trabalho "Inventário do Feminino" que é de autoria de Juliano Baby Amorim. Todas as fotografias dos meus trabalhos são de minha autoria e podem ser acessadas no meu site: http:// www.anasabia.com

16 Boneca russa feita em madeira e pintada à mão que tem a particularidade de ser oca por dentro para acondicionar outra bonecas em seu interior. Aquela que ali se aninha, por sua vez, acondiciona outra boneca menor e assim sucessivamente até a menor delas restar.

17 Referenciando o título do trabalho de Sara Ramos

18 B/W: siglas para Black and White (Preto e Branco)

19 "O estilo Luís XV designa um estilo de decoração de interiores e mobiliário que se desenvolve a partir de França durante o reinado de Luís XV, entre aproximadamente 1730 e 1750-60 (não englobando todo o período do reinado até 1774). Este estilo é influenciado pelas linhas fluidas e graciosas do rococó e pelo seu repertório de motivos ornamentais, situando-se entre o estilo regência, onde já dá os primeiros passos, e o estilo Luís XVI, que se caracteriza por uma maior rigidez e austeridade. É considerado um dos estilos estéticos franceses de maior impacto, sendo, por isso, alvo dos mais diversos revivalismos ao longo do tempo." Fonte: Wikipedia

20 Revista Veja, 18/04/2016, Fonte:http://veja.abril.com.br/noticia/brasil/bela-recatada-e-do-lar

21 Poder não como algo que se detenha mas como tecido político, micropolítica do poder e jogos sociais perspectivados por Michel Foucault (1995).

220 ex-voto é o presente dado pelo fiel ao seu santo de devoção em consagração, renovação ou agradecimento de uma promessa. O advento da oferta votiva abre ou fecha um ciclo transacional que se imagina tão antigo quanto a própria existência humana. Trata-se de 
uma expressão moderna da relação entre o frágil mundo dos homens e o inexorável mundo dos deuses. É uma relação cujo modelo estrutural se mantém semelhante em diferentes matrizes religiosas, desde a Antiguidade. Fonte: Wikipedia

23 Existem vários significados atribuídos aos macacos e ao provérbio que incluem associações com estar de boa mente, fala e ação. No mundo ocidental a frase é muitas vezes usada para se referir àqueles que lidam com impropriedade por fazer vista grossa. Fonte Wikipedia

24 SABIÁ, A.P. Bela, recatada e do lar: entre discurso de controle e resistência artístico-política nas artes contemporâneas. ANPAP 2016

\section{Fonte: Wikipedia}

26 Como acredita Deleuze no livro "Diferença e repetição" (1988)

27 O iCloud é o sistema de armazenamento virtual na nuvem da Apple que atua de maneira bastante sofisticada para salvar arquivos 28 DERRIDA, J. 2002

29 MALRAUX, A. 2000.

\section{Referências}

BENJAMIN, Walter. Obras escolhidas. S.P.: Brasiliense, vl I a III, 1985-1988.

CHEREM, Rosangela. Anotações de aulas da disciplina Territorialidades Modernas e Contemporâneas, PPGAV-UDESC 2016.

DELEUZE, Gilles. O que é filosofia. R.J.: Ed. 34, 1993

DELEUZE, Gilles \& GUATTARI, Félix. Diferença e Repetição. R.J.: Graal, 1988.

DERRIDA, Jacques. Mal de Arquivo. Rio de Janeiro: RELUME-Dumará:2002.

DERRIDA, Jacques. Torres de babel. Belo Horizonte: UFMG, 2002.

FOUCAULT, Michel. Arqueologia do saber. Rio de Janeiro: Forense Universitária, 1995.

GUASCH, Anna Maria. Arte y archivo. 1920-2010. Genealogías, tipologias y descontinuidades. Madrid: Ed. Akal, S.A., 2011.

MALRAUX, André. O museu imaginário. Lisboa: Ed. 70, 2000

ROMERO, Pedro: Um conocimiento por el montaje. Entrevista com Georges Didi-Huberman. Madrid, 2007. In: http://www.circulobellasartes.com/ag_ediciones-minerva- LeerMinervaCompleto. php?art=141\&pag=5\#leer

\section{Sites das artistas}

SARA RAMOS: http://www.sararamos.com.br

ANA SABIÁ: http://www.anasabia.com 